\title{
Evaluasi Pemanfaatan PLTS Terpusat Siding Kabupaten Bengkayang
}

\author{
Eriyanto \\ Program Studi Manajemen Energi, Magister Teknik Elektro \\ Fakultas Teknik, Universitas Tanjungpura Pontianak \\ Staf Kementerian Perhubungan Kantor KSOP Pontianak \\ email : ery_tasura@yahoo.co.id
}

\begin{abstract}
PLTS Siding memiliki kapasitas setara 40 $k W p$ dengan jumlah pelanggan yang tersambung sebanyak 52 pelanggan dan total beban sebesar 31.700 VA. Untuk mengetahui tingkat daya-guna PLTS Terpusat (Off-Grid) Siding ditinjau dari kapasitas sistem PLTS dalam melayani kebutuhan tenaga listrik bagi masyarakat Desa Siding, perlu melakukan studi dan meneliti tentang unjuk kerja dari PLTS Terpusat Siding dengan mengevaluasi daya yang dibangkitkan PLTS Siding, menghitung kapasitas komponen PLTS yang terpasang, serta analisis kelayakan investasi PLTS Siding dengan metode : Net Present Value (NPV), Profitability Index (PI), dan Payback Periode. Berdasarkan hasil evaluasi kapasitas komponenkomponen PLTS Siding masih layak digunakan untuk pelayanan beban. Perhitungan biaya investasi awal untuk PLTS Siding sebesar Rp. 2.662.800.000,00, diperoleh biaya energi (cost of energy) PLTS Siding sebesar Rp. 4.600,00/kWh. Hasil analisis kelayakan investasi menunjukkan bahwa investasi PLTS Siding sebagai sumber tenaga listrik di Kecamatan Siding termasuk layak untuk dilaksanakan. Dengan memaksimalkan pemanfaatan PLTS Terpusat Siding melalui penambahan beban sehingga terjadi penambahan pemakaian energi harian sebesar 226,24 kWh/hari, akan menurunkan biaya energi PLTS Siding sebesar Rp. 4.600/kWh menjadi 3.500/kWh.
\end{abstract}

Keywords- PLTS, insolasi matahari, charge controller, inverter, cost of energy

\section{Pendahuluan}

PLTS Siding dibangun tanggal 20 Januari 2012, dan mulai beroperasi tanggal 7 Mei 2013. Sumber dana pembangunan PLTS Siding dari PT.PLN (Persero) Wilayah Kalimantan Barat. PLTS Siding terletak di Dusun Padang, Desa Siding, Kecamatan Siding, Kabupaten Bengkayang, Provinsi Kalimantan Barat.

PLTS Terpusat Siding menggunakan Off Grid System yang dirancang beroperasi mandiri dengan pemanfaatan array photovoltaic saja, dan tidak menggunakan sumber tambahan energi lain.. Daya yang dihasilkan dari PLTS tersebut setara $40 \mathrm{kWp}$ dan bisa melayani 100 kepala keluarga dengan daya masingmasing rumah $450 \mathrm{VA}$. Pada saat ini jumlah pelanggan yang tersambung sebanyak 52 pelanggan dengan daya total tersambung sebesar 31.700 VA. PLTS Siding dengan tegangan input 240 VDC (arus searah) dan tegangan output tiga fasa 220/380 VAC (arus bolakbalik) yang dibangkitkan oleh inverter 3 (tiga) fasa dan langsung didistribusikan ke rumah-rumah pelanggan melalui sistem distribusi jaringan tegangan rendah.

Pada penelitian ini, untuk mengetahui tingkat dayaguna pemanfaatan PLTS Terpusat (Off-Grid) Siding ditinjau dari kapasitas sistem PLTS dalam melayani kebutuhan tenaga listrik bagi masyarakat Desa Siding diperlukan evaluasi unjuk kerja PLTS Terpusat Siding meliputi kapasitas daya, panel surya, baterai, dan inverter yang terpasang, serta analisis kelayakan investasi PLTS Terpusat Siding dengan metode : Net Present Value (NPV), Profitability Index (PI), dan Payback Periode. Disamping itu pada penelitian ini menganalisis pengaruh pemanfaatan PLTS Terpusat Siding secara maksimal dengan biaya energi yang dihasilkan.

\section{Dasar Teori}

\subsection{Kapasitas Komponen PLTS}

\subsubsection{Jumlah Panel Surya}

Daya (wattpeak) yang dibangkitkan PLTS untuk memenuhi kebutuhan energi, diperhitungkan dengan persamaan-persamaan sebagai berikut : [1]

\section{1) Menghitung Area Array (PV Area)}

Area array ( $P V$ Area) diperhitungkan dengan menggunakan rumus sebagai berikut :

PV Area $=\frac{E_{L}}{G_{\text {av }} \times \text { TCF } \times \eta \text { PV } \times \text { nout }}\left[\mathrm{m}^{2}\right]$.

Dimana :

$\mathrm{E}_{\mathrm{L}} \quad=$ Energi yang dibangkitkan $[\mathrm{kWh} / \mathrm{hari}]$

PV Area $=$ Luas permukaan panel surya $\left[\mathrm{m}^{2}\right]$

$\mathrm{G}_{\mathrm{av}}=$ Intensitas Matahari harian $\left[\mathrm{kW} / \mathrm{m}^{2} /\right.$ hari $]$

$\mathrm{TCF}=$ Temperature coefficient factor $[\%]$

$\eta \mathrm{PV} \quad=$ Efisiensi panel surya [\%]

nout $=$ Efisiensi keluaran [\%] asumsi 0,9

\section{2) Menghitung Daya yang Dibangkitkan PLTS (watt peak)}

Dari perhitungan area array, maka besar daya yang dibangkitkan PLTS (wattpeak) dapat diperhitungkan dengan rumus sebagai berikut :

$\mathrm{P}_{\text {watt peak }}=$ PV Area $\times$ PSI $x \eta \mathrm{PV}$ [watt $]$

Dimana :

PV Area $=$ Luas permukaan panel surya $\left[\mathrm{m}^{2}\right]$ 
PSI = Peak Solar Insolation adalah $1.000 \mathrm{~W} / \mathrm{m}^{2}$

$\eta \mathrm{PV}=$ Efisiensi panel surya $[\%]$

Selanjutnya berdasarkan besar daya yang akan dibangkitkan (wattpeak), maka jumlah panel surya yang diperlukan, diperhitungkan dengan rumus sebagai berikut :

Jumlah panel surya $=\frac{\mathrm{P}_{\text {watt peak }}}{\mathrm{P}_{\mathrm{MPP}}} \quad[$ unit $]$

Dimana :

$\mathrm{P}_{\text {watt peak }}=$ Daya yang dibangkitkan $\left[\mathrm{W}_{\mathrm{P}}\right]$

$\mathrm{P}_{\mathrm{MPP}}=$ Daya maksimum keluaran panel surya [watt]

\subsubsection{Kapasitas Charge Controller}

Kapasitas Charge controller ditentukan dengan rumus sebagai berikut : [2]

Capacity of Charge Controller $=$

$\frac{\text { Demand watt x Safety Factor }}{\text { System Voltage }}$ [ampere]

Dimana safety factor (faktor keamanan) ditentukan sebesar 1,25.

\subsubsection{Kapasitas Baterai}

Besar kapasitas baterai yang dibutuhkan untuk memenuhi konsumsi energi harian dapat dihitung dengan rumus sebagai berikut : [3]

$\mathrm{C}=\frac{\mathrm{N}_{\mathrm{N}} \mathrm{E}_{\mathrm{d}}}{\mathrm{V}_{\mathrm{S}} \times \mathrm{DOD} \times \eta}[\mathrm{Ah}]$

Dimana :

C = Kapasitas baterai [Ampere-hour]

$\mathrm{N} \quad=$ Jumlah hari otonomi [hari]

$\mathrm{E}_{\mathrm{d}} \quad=$ Konsumsi energi harian $[\mathrm{kWh}]$

$\mathrm{V}_{\mathrm{S}} \quad$ = Tegangan baterai [Volt]

DOD = Kedalaman maksimum untuk pengosongan baterai [\%]

$\eta \quad=$ Efisiensi baterai $\mathrm{x}$ efisiensi inverter

\subsubsection{Kapasitas Inverter}

Kapasitas inverter ditentukan dengan rumus sebagai berikut : [2]

Cap. Inv $=$ Demand watt $\mathrm{x}$ Safety Factor [watt]

\subsection{Aspek Biaya}

\subsubsection{Biaya Siklus Hidup (Life Cycle Cost)}

Biaya siklus hidup suatu sistem adalah semua biaya yang dikeluarkan oleh suatu sistem, selama kehidupannya. Pada sistem PLTS, biaya siklus hidup (LCC) ditentukan oleh nilai sekarang dari biaya total sistem PLTS yang terdiri dari biaya investasi awal, biaya jangka panjang untuk pemeliharaan dan operasional serta biaya penggantian baterai.

\section{1) Biaya Investasi PLTS}

Biaya investasi awal PLTS Terpusat Terpusat Siding Kabupaten Bengkayang mencakup biaya-biaya seperti : biaya umum, biaya pekerjaan mekanikal dan elektrikal, dan biaya pekerjaan sipil. Biaya-biaya tersebut merupakan nilai kontrak untuk pembangunan PLTS Terpusat Terpusat Siding Kabupaten Bengkayang.

\section{2) Biaya Pemeliharaan dan Operasional}

Adapun besar biaya pemeliharaan dan operasional (M) per tahun untuk PLTS yang akan dikembangkan adalah sebagai berikut : [5]

$\mathrm{M}=1 \% \mathrm{x}$ Total biaya investasi [Rp]

Biaya siklus hidup (LCC) diperhitungkan dengan rumus sebagai berikut :

$\mathrm{LCC}=\mathrm{C}+\mathrm{M}_{\mathrm{PW}}$

Dimana :

LCC = Biaya siklus hidup (Life Cycle Cost) .

$\mathrm{C}=$ Biaya investasi awal adalah biaya awal yang dikeluarkan untuk pembelian komponenkomponen PLTS, biaya instalasi dan biaya lainnya misalnya biaya untuk rak penyangga.

MPW = Biaya nilai sekarang untuk total biaya pemeliharaan dan operasional selama $n$ tahun atau selama umur proyek.

Nilai sekarang biaya tahunan yang akan dikeluarkan beberapa tahun mendatang (selama umur proyek), dengan jumlah pengeluaran yang tetap, dihitung dengan rumus sebagai berikut : [6]

$\mathrm{M}_{\mathrm{PW}}=\mathrm{A}\left[\frac{(1+\mathrm{i})^{\mathrm{n}}-1}{\mathrm{i}(1+\mathrm{i})^{\mathrm{n}}}\right]$

Dimana :

$\mathrm{M}_{\mathrm{PW}}=$ Nilai sekarang biaya tahunan selama umur proyek.

A = Biaya tahunan

$\mathrm{i} \quad=$ Tingkat diskonto

$\mathrm{n} \quad=$ Umur proyek

\section{3) Faktor Diskonto}

Faktor diskonto (Discount factor) adalah faktor yang digunakan untuk menilaisekarangkan penerimaanpenerimaan di masa mendatang sehingga dapat dibandingkan dengan pengeluran pada masa sekarang. Adapun rumus faktor diskonto adalah sebagai berikut : [7]

$\mathrm{DF}=\frac{1}{(1+\mathrm{i})^{\mathrm{n}}}$

DF $=$ Faktor Diskonto

$\mathrm{i} \quad=$ Tingkat diskonto

$\mathrm{n} \quad=$ Periode dalam tahun (umur inverstasi)

\subsubsection{Biaya Energi (Cost of Energy)}

Perhitungan biaya energi suatu PLTS ditentukan oleh biaya siklus hidup (LCC), faktor pemulihan modal (CRF) dan $\mathrm{kWh}$ produksi tahunan PLTS.

\section{1) Faktor Pemulihan Modal (Capital Recovery Factor)}

Faktor pemulihan modal diperhitungkan dengan rumus sebagai berikut : [6]

$\mathrm{CRF}=\frac{\mathrm{i}(1+\mathrm{i})^{\mathrm{n}}}{(1+\mathrm{i})^{\mathrm{n}}-1}$

dengan $\mathrm{n}$ adalah periode (umur) proyek.

Menurut Wengqiang dkk, (2004), perumusan

biaya energi adalah sebagai berikut : [4]

$\mathrm{COE}=\frac{\mathrm{LCC} \times \mathrm{CRF}}{\mathrm{AKWH}}$

Dimana : 
$\mathrm{COE}=$ Cost of Energy / Biaya Energi $(\mathrm{Rp} / \mathrm{kWh})$

LCC = Biaya siklus hidup (Life Cycle Cost).

$\mathrm{CRF}=$ Faktor Pemulihan Modal, berdasarkan pada discount rate (i).

$\mathrm{AKWH}=$ Energi yang dibangkitkan tahunan (kWh/tahun)

\subsection{Analisis Kelayakan Investasi PLTS}

Kelayakan investasi PLTS ditentukan berdasarkan hasil perhitungan Net Present Value (NPV), Profitability Index (PI) dan Payback Period (PP).

\subsubsection{Net Present Value (NPV)}

Net Present Value (NPV) menyatakan bahwa seluruh aliran kas bersih dinilai sekarang atas dasar faktor diskon (discount factor). Untuk menghitung Net Present Value (NPV) dipergunakan rumus sebagai berikut : [7] $\mathrm{NPV}=\sum_{\mathrm{t}=1}^{\mathrm{n}} \frac{\mathrm{NFC}_{\mathrm{t}}}{(1+\mathrm{i})^{\mathrm{t}}}-\mathrm{II}$

Kriteria pengambilan keputusan apakah usulan investasi layak diterima atau layak ditolak adalah sebagai berikut :

1) Investasi dinilai layak, apabila Net Present Value (NPV) bernilai positif ( $>0)$.

2) Investasi dinilai tidak layak, apabila Net Present Value (NPV) bernilai negative $(<0)$.

\subsubsection{Profitability Index (PI)}

Profitability Index merupakan perbandingan antara seluruh kas bersih nilai sekarang dengan investasi awal. Teknik ini juga sering disebut dengan model rasio manfaat biaya (benefit cost ratio). Teknik Profitability Index dihitung dengan rumus sebagai berikut : [7]

$\mathrm{PI}=\frac{\sum_{\mathrm{t}=\mathrm{i}}^{\mathrm{n}} \mathrm{NCF}_{\mathrm{t}}(1+\mathrm{i})^{-\mathrm{t}}}{\mathrm{II}}$

Kriteria pengambilan keputusan apakah usulan investasi layak diterima atau layak ditolak adalah sebagai berikut :

1) Investasi dinilai layak, apabila Profitability Index (PI) bernilai lebih besar dari satu $(>1)$.

2) Investasi dinilai tidak layak, apabila Profitability Index (PI) bernilai lebih kecil dari satu $(<1)$.

\subsubsection{Discounted Payback Periode}

Payback Period adalah periode lamanya waktu yang dibutuhkan untuk mengembalikan nilai investasi melalui penerimaan-penerimaan yang dihasilkan oleh proyek (investasi). Teknik DPP dirumuskan sebagai berikut : [7]

$D P P=$ Year before recovery $+\frac{\text { Invesment Cost }}{\text { NPV Kumulatif }}$

Kriteria pengambilan keputusan apakah usulan investasi layak diterima atau layak ditolak adalah :

1) Investasi dinilai layak, apabila DPP memiliki periode waktu lebih pendek dari umur proyek (periode cutoff).

2) Investasi dinilai tidak layak, apabila DPP memiliki periode waktu lebih panjang dari umur proyek (periode cutoff).
Dimana :

$\mathrm{NCF}_{\mathrm{t}}=$ Net Cash Flow periode tahun ke-1 sd ke-n.

II = Investasi awal (Initial Investment).

i = Discount factor

$\mathrm{n}=$ Periode dalam tahun (umur investasi).

Year before recovery = Jumlah tahun sebelum tahun pengembalian final

Investment Cost = Biaya investasi awal.

NPV Kumulatif = Jumlah kas bersih nilai

\subsection{Diagram Alir Penelitian}

Evaluasi pemanfaatan PLTS Siding Kabupaten Bengkayang dapat digambarkan dalam bentuk diagram alir sebagai berikut :

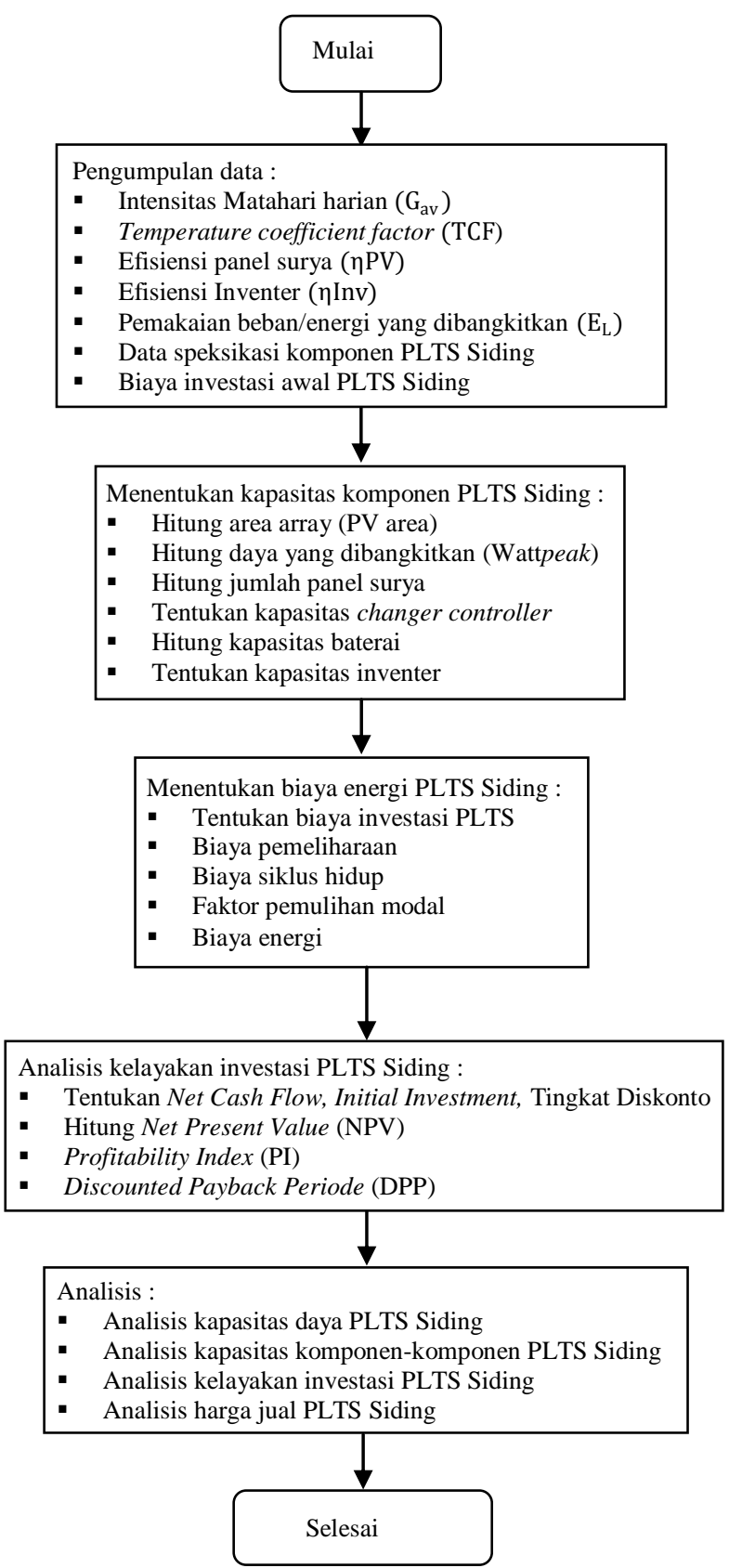

Gambar 1. Diagram Alir Evaluasi Pemanfaatan PLTS Siding Kabupaten Bengkayang 


\section{Analisis PLTS Siding}

\subsection{Analisis Kapasitas Daya PLTS Siding}

Perhitungan kapasitas daya PLTS Siding membutuhkan data-data dilapangan antara lain : pemakaian energi listrik pelanggan PLTS, data insolasi harian matahari dan data temperatur maksimum untuk wilayah Kecamatan Siding yang ditunjukkan pada tabel dibawah ini :

Tabel 1. Data Perhitungan Kapasitas PLTS Siding

\begin{tabular}{clcc}
\hline \hline No & \multicolumn{1}{c}{ Nama Data } & Nilai & Satuan \\
\hline 1 & Potensi Energi Matahari & 4,09 & $\mathrm{kWh} / \mathrm{m}^{2} / \mathrm{hari}$ \\
\hline 2 & Temperatur Maksimum & 28,8 & ${ }^{\circ} \mathrm{C}$ \\
\hline 3 & $\begin{array}{l}\text { Pemakaian Energi PLTS } \\
\text { Harian }\end{array}$ & 147 & $\mathrm{kWh} / \mathrm{hari}$ \\
\hline 4 & Modul Panel & 200 & Wattpeak \\
\hline 5 & Efisiensi Panel Surya & 15 & $\%$ \\
\hline 6 & Efisiensi Keluaran & 90 & $\%$ \\
\hline
\end{tabular}

Dengan menggunakan data-data pada Tabel 1, perbandingan besarnya perhitungan kapasitas daya PLTS Siding dengan kapasitas daya PLTS Siding yang terpasang (existing) dapat ditunjukkan pada tabel dibawah ini :

Tabel 2. Perbandingan Kapasitas PLTS Siding

\begin{tabular}{clcc}
\hline \hline No & \multicolumn{1}{c}{ Uraian } & Perhitungan & $\begin{array}{c}\text { PLTS } \\
\text { Existing }\end{array}$ \\
\hline 1 & Pwattpeak (Watt) & $40.708,5$ & 40.000 \\
\hline 2 & PV Area $\left(\mathrm{m}^{2}\right)$ & 271,39 & 266,66 \\
\hline 3 & $\begin{array}{l}\text { Jumlah Panel } \\
\text { (unit) }\end{array}$ & 204 & 200 \\
\hline
\end{tabular}

\subsection{Analisis Kapasitas Komponen-Komponen PLTS Siding}

Berdasarkan perhitungan kapasitas komponenkomponen PLTS Siding yang telah dilakukan. Perbandingan besarnya perhitungan kapasitas komponen-komponen PLTS Siding dengan kapasitas komponen-komponen PLTS Siding yang terpasang (existing) dapat ditunjukkan pada tabel dibawah ini :

Tabel 3. Perbandingan Kapasitas Komponen PLTS Siding

\begin{tabular}{clcc}
\hline \hline No & \multicolumn{1}{c}{ Komponen } & Perhitungan & $\begin{array}{c}\text { PLTS } \\
\text { Existing }\end{array}$ \\
\hline 1 & $\begin{array}{l}\text { Charge controller } \\
\text { (Ampere) }\end{array}$ & 65,79 & 125 \\
\hline 2 & Baterai (Ah) & $360 @ 3.000 \mathrm{Ah}$ & $\begin{array}{c}360 \\
@ 3.000 \mathrm{Ah}\end{array}$ \\
\hline 3 & Inverter (Watt) & 25.000 & 30.000 \\
\hline
\end{tabular}

\subsection{Analisis Kelayakan investasi PLTS Siding}

Untuk mempertimbangkan kelayakan investasi PLTS Siding sebagai sumber tenaga listrik di Kecamatan Siding, perlu dilakukannya suatu analisis ekonomi. Kelayakan investasi PLTS Siding ditentukan berdasarkan hasil perhitungan Net Present Value (NPV), Profitability Index (PI) dan Payback Period (PP), ditunjukkan pada tabel di bawah ini :
Tabel 4. Perhitungan Biaya Energi dan Kelayakan Investasi PLTS Siding

\begin{tabular}{lr}
\hline Biaya Investasi PLTS (Rp) & $\mathbf{2 . 6 6 2 . 8 0 0 . 0 0 0 , 0 0}$ \\
\hline $\begin{array}{l}\text { Biaya Operasional dan } \\
\text { Pemeliharaan PLTS (Rp) }\end{array}$ & $\mathbf{2 6 . 6 2 8 . 0 0 0 , 0 0}$ \\
\hline Biaya Siklus Hidup (LCC) & \\
\hline Umur Proyek (tahun) & 6,50 \\
\hline Suku Bunga (\%) & $612.63 .768,00$ \\
\hline $\begin{array}{l}\text { Biaya Pemeliharaan \& } \\
\text { Operasional (present value) }\end{array}$ & Rp. $2.987 .608 .344,00$ \\
\hline $\begin{array}{l}\text { Total Biaya Siklus Hidup } \\
\text { Selama 25 Tahun (Rp) }\end{array}$ & \\
\hline Biaya Energi (Cost of Energy)
\end{tabular}

\begin{tabular}{ll}
$\begin{array}{l}\text { Biaya Energi (Cost of Energy) } \\
\text { (Rp/kWh) }\end{array}$ & $\mathbf{4 . 6 0 0}$ \\
\hline $\begin{array}{l}\text { Analisis Kelayakan Investasi } \\
\text { PLTS }\end{array}$ \\
\hline Net Present Value (NPV) & Rp. $22.989 .487,00$ \\
\hline Profitability Index (PI) & 1,009 \\
\hline Discounted Payback Periode & 24 tahun 6 bulan \\
\hline
\end{tabular}

\subsection{Analisis Harga Energi PLTS Siding}

Biaya energi PLTS Siding sebesar Rp. 4.600/kWh dibandingkan dengan biaya pokok penyediaan (BPP) listrik PLN untuk yang besarnya adalah $\mathrm{Rp}$. $1.457,72 / \mathrm{kWh}$ (penetapan tarif listrik bulan September 2016, maka hal tersebut menunjukkan bahwa untuk saat ini biaya energi PLTS masih lebih mahal dari PLN. Untuk menjaga penyediaan tenaga listrik pada PLTS Siding tetap berlangsung dalam memenuhi pasokan tenaga listrik pada Kecamatan Siding perlu diberlakukannya subsidi listrik dari Pemerintah.

\subsection{Analisis Pemanfaatan PLTS Siding}

Berdasarkan hasil analisis diatas, besarnya daya yang dapat dibangkitkan PLTS sebesar 44.444 VA sedangkan besarnya beban yang terpasang pada PLTS Terpusat Siding sebesar $31.700 \mathrm{VA}$ atau sebesar $71 \%$. Sehingga daya yang masih dapat disalurkan untuk melayani beban yang akan datang sebesar $12.744 \mathrm{VA}$ atau sebesar $29 \%$. Perbandingan besarnya beban yang terpasang dan besarnya cadangan daya yang tersedia ditunjukkan dengan grafik pada gambar 4.3.

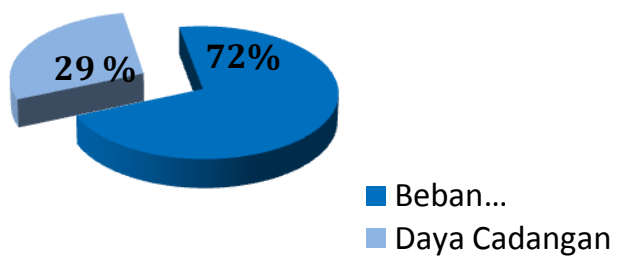

Gambar 2. Grafik Perbandingan Beban dan Daya Cadangan 
Diasumsikan terjadi penambahan jumlah pelanggan PLTS Terpusat Siding sebanyak 28 pelanggan dengan daya $450 \mathrm{VA}$ akan menambah pemakaian energi listrik harian sebesar $28 \times 2,83 \mathrm{kWh}=79,24 \mathrm{kWh} / \mathrm{hari}$, sehinggi total pemakaian energi listrik harian PLTS Terpusat Siding sebesar $147 \mathrm{kWh}+79,24 \mathrm{kWh}=$ $226,24 \mathrm{kWh} / \mathrm{hari}$.

Sehingga besar kapasitas baterai yang dibutuhkan untuk memenuhi konsumsi energi harian PLTS Siding dengan mempertimbangkan hari otonomi selama 3 hari menjadi :

$$
\begin{aligned}
\mathrm{C} & =\frac{\mathrm{N} \times \mathrm{E}_{\mathrm{d}}}{\mathrm{V}_{\mathrm{S}} \times \mathrm{DOD} \times \eta} \\
& =\frac{3 \times 226.240}{240 \times 0,8 \times 0,9} \\
& =3.927,77 \mathrm{Ah}(\text { yang tersedia } 4 \times 1000 \mathrm{Ah})
\end{aligned}
$$

Dengan harga baterai sebesar Rp. 3.600.000,00 per unit akan menambah biaya untuk komponen baterai sebesar 120 x Rp. 3.600.000,00 = Rp. 432.000.000,00, sehingga total investasi PLTS menjadi Rp. 3.094.800.000,00.

Biaya pemeliharaan dan pemeriksaan peralatan dan instalasi akan ditetapkan sebesar $1 \%$ dari total biaya investasi awal.

$$
\begin{aligned}
\mathrm{M}_{\mathrm{PW}} & =1 \% \times \text { Rp. 3.094.800.000,00 } \\
& =\text { Rp. 30.948.000,00/Tahun }
\end{aligned}
$$

Biaya pemeliharaan dan operasional $\left(\mathrm{M}_{\mathrm{PW}}\right)$ PLTS Siding selama umur proyek 25 tahun dengan tingkat diskonto $6,50 \%$ adalah :

$$
\begin{aligned}
& \mathrm{M}_{\mathrm{PW}}(6,50 \%, 25) \\
& \begin{aligned}
\text { Rp. 30.948.000,00 }\left[\frac{(1+0,065)^{25}-1}{0,65(1+0,65)^{25}}\right] \\
=\text { Rp. 30.948.000,00 }\left[\frac{3,8277}{0,3138}\right] \\
=\text { Rp. 377.503.704,00 }
\end{aligned}
\end{aligned}
$$

Berdasarkan biaya investasi awal I dan perhitungan MPW maka biaya siklus hidup (LCC) untuk PLTS Siding selama umur proyek 25 tahun adalah sebagai berikut :

$$
\begin{aligned}
\mathrm{LCC} & =\mathrm{C}+\mathrm{M}_{\mathrm{PW}} \\
& =\text { Rp. } 3.094 .800 .000,00+\text { Rp. } 377.503 .704,00 \\
& =\text { Rp. 3.472.303.704,00 }
\end{aligned}
$$

Dengan penambahan pemakaian energi harian sebesar 226,24 kWh/hari, kWh produksi tahunan PLTS Siding diperhitungkan sebagai berikut :

$\mathrm{AKWH}=\mathrm{kWh}$ harian $\times 365[\mathrm{kWh}]$

$$
\begin{aligned}
& =226,24 \times 365[\mathrm{kWh}] \\
& =82.578 \mathrm{kWh}
\end{aligned}
$$

Berdasarkan hasil perhitungan LCC, CRF dan kWh produksi tahunan, maka besar biaya energi (COE) untuk PLTS Siding sebagai berikut :

$$
\begin{aligned}
\mathrm{COE} & =\frac{\mathrm{LCC} \times \mathrm{CRF}}{\mathrm{AKWH}} \\
& =\frac{\text { Rp. } 3.472 .303 .704 \times 0,0820}{82.578} \\
& =\text { Rp. } 3.447,238 / \mathrm{kWh} \\
& =\text { Rp. } 3.500 / \mathrm{kWh}
\end{aligned}
$$

Dengan memaksimalkan pemanfaatan PLTS Terpusat Siding melalui penambahan beban, akan menurunkan biaya energi PLTS Siding sebesar Rp. 4.600/kWh menjadi 3.500/kWh

\section{Kesimpulan}

Dari evaluasi pemanfaatan PLTS Siding Kabupaten Bengkayang, dapat diambil beberapa kesimpulan sebagai berikut :

1. Dengan potensi energi matahari wilayah Kecamatan Siding dan besarnya pemakaian energi pelanggan PLTS Siding, perhitungan daya yang dibangkitkan oleh PLTS Siding sebesar 40.708,5 Wattpeak, dengan panel surya $200 \mathrm{Wp}$ sebanyak 204 unit.

2. Berdasarkan hasil perhitungan dapat disimpulakn kapasitas komponen-komponen PLTS Siding yaitu : charge controller dan inverter yang terpasang pada PLTS Siding masih jauh diatas dari kapasitas maksimum yang diijinkan.

3. Perhitungan biaya energi (cost of energy) suatu PLTS Siding sebesar Rp. 4.600,00/kWh.

4. Hasil analisis kelayakan investasi yaitu : perhitungan NPV yang bernilai positif sebesar Rp. 22.989.487,00, perhitungan PI yang bernilai 1,009, dan perhitungan DPP sekitar 24 tahun 6 bulan.

5. Dengan memaksimalkan pemanfaatan PLTS Terpusat (Off-Grid) Siding melalui penambahan beban sehingga terjadi penambahan pemakaian energi harian sebesar 226,24 kWh/hari, akan menurunkan biaya energi PLTS Siding sebesar Rp. 4.600/kWh menjadi 3.500/kWh.

\section{Referensi}

[1] Nafeh, A.E.A., 2009 Design and Economic Analysis of a Stand-Alone PV System to Electrify a Remote Area Household in Egypt. The Open Renewable Energy Journal 2 : 33-37.

[2] Muzzammir. Md. Naim, Foraji Abdullah Al Masum. 2014. An economic Analysis of Solar PV System in Bangladesh. Departement of Electrical and Electronics Engineering. Daffodil International University.

[3] Lynn, PA. 2010. Electricity from Sunlight : An Introduction Photovoltaic. London : Jhon Wiley \& Sons, $\mathbf{L t d}$.

[4] Wenqiang, L. Shuhua, G. Daxiong, Q., 2004. TechnoEconomic Assesment For Off-Grid Hybrid Generation System and Application Prospects in China. World Energy Council. London.

[5] Lazou, and Papatsoris. 2000. The Economics of Photovoltaic Stand-Alone Reidential Household : $\boldsymbol{A}$ Case Study for VariousEuropean and Mediterranean Locations. Solar Energy Material \& Solar Cells 62 : 411-427

[6] Al-Qutub, R.W.A. 2010. "Treatment of Surface Water by Autonomous Solar-Powered Membrane Cells"(tesis). Palestine : An-Najah National University.

[7] Halim, A. 2009. Analisis Kelayakan Investasi Bisnis. Yogyakarta : Graha Ilmu. 
[8] Ariani, Wisna Dwi, dkk. 2014. Analisis Kapasitas dan Biaya Pembangkit Listrik Tenaga Surya (PLTS) Komunal Desa Kaliwungu Kabupaten Banjarnegara. Jurnal Transient, Vol 3, no. 2, Juni 2014.

[9] Muzzammir. Md. Naim, Foraji Abdullah Al Masum. 2014. An economic Analysis of Solar PV System in Bangladesh. Departement of Electrical and Electronics Engineering. Daffodil International University.

[10] Nafis, dkk. 2015. Analisis Keekonomian Penerapan Pembangkit Listrik Tenaga Surya Pada Sistem Ketenagalistrikan Nias. Jurnal Ketenagalistrikan Dan Energi Terbarukan, Vol 14, no. 2 desember 2015, 8394.

\section{Biografi}

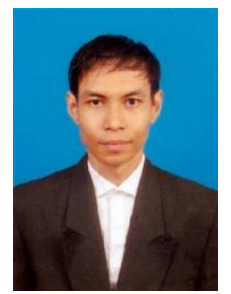

Eriyanto, lahir di Ketapang pada tanggal 18 September 1980. Lulus S1 tahun 2007 fakultas Teknik UNTAN Jurusan Teknik Elektro dan menempuh Pendidikan S2 di Fakultas Teknik Universitas Tanjungpura sejak tahun 2015 dan lulus pada tahun 2017. Sejak tahun 2008 bekerja di Kementerian Perhubungan, dan sekarang ditempatkan di Kantor KSOP Pontianak. 